\title{
Tubular formations extending from parasitophorous vacuoles in gut epithelial cells of cichlid fish infected by Eimeria (s.l.) vanasi
}

\author{
I. Paperna ${ }^{1}$ \& J. H. Landsberg ${ }^{2}$ \\ ${ }^{1}$ Department of Animal Sciences, Faculty of Agriculture, Hebrew University of Jerusalem, Rehovot 76-100, Israel \\ ${ }^{2}$ Laboratory for Research of Fish Diseases, Nir David 19150, Israel
}

\begin{abstract}
An ultrastructural study of the gut epithelium of cultured juveniles of Oreochromis aurea $\times O$. niloticus hybrids infected with the coccidian Eimeria (s.l.) vanasi Landsberg \& Paperna in press revealed the presence of numerous tubuli extending from funnels located at the border of the parasitophorous vacuole. These tubuli were most abundant in host cells infected with gamonts, while being fewer, vestigial or absent in cells infected by merogony stages. Such tubular structures have not previously been reported in host cells infected with coccidians.
\end{abstract}

Cichlid fish in Israel and South Africa were found to be infected with Eimeria (s.l.) vanasi Landsberg \& Paperna in press. Endogenuous development of this coccidian occurs in both the interior and at the microvillar zone of the mucosal epithelial cells of the intestine (Landsberg \& Paperna in press). Stages developing in the microvillar zone closely resemble species of the genus Epieimeria (Dyková \& Lom 1981, Molnár \& Baska 1986). In the present communication we report on the finding of tubular formations in the infected gut epithelial cells not reported so far in any other coccidian infections.

Materials and Methods. Study material from hybrid fry and fingerlings (10 to $25 \mathrm{~mm}$ in length) of Oreochromis aureus (Steindachner) $\times$ O. niloticus (L.) was obtained from hatcheries in the Jordan valley, Israel. For transmission electron microscopy (TEM), intestinal samples from the infected fish were fixed in Karnovski for $24 \mathrm{~h}$ in $4{ }^{\circ} \mathrm{C}$, rinsed repeatedly in cacodylate buffer (0.1 M, pH 7.4) and postfixed in $1 \%$ osmium tetroxide, in the same buffer, for $1 \mathrm{~h}$. After rinsing in the buffer, the material was dehydrated in ethanol and embedded in Epon. Thin sections cut on a LKB III ultratome with a diamond knife were stained on the grid with uranyl acetate and lead citrate and examined with a Joel $100 \mathrm{CX}$ TEM.
Results and Discussion. The cytoplasm of infected cells contained numerous robust straight tubules (60 to $80 \mathrm{~nm}$ in diameter) which extended from 160 to $180 \mathrm{~nm}$ wide funnels, located at regular intervals along the border of the parasitophorous vacuole (PV) (Fig. 1 to 4). Both the tubule and the wall of the funnel developed from invaginations of the bilaminated wall of the PV. The funnel lumen and the core of the tubule were filled with an electron-dense substance. The core was separated from the tubule and the funnel wall by an electron-lucent interphase. The electron-dense material of the core extended slightly into the lumen of the PV (Fig. 5). This may be suggestive of an excreted liquid substance which coagulated after fixation. In some cells, tubuli were accompanied by numerous mitochondria (Fig. 6).

Tubuli were abundant in epithelial cells infected by early gamonts (Fig. 1), macrogamonts, early stage zygotes (Fig. 2) and microgamonts (Fig. 7). The early stage zygotes were enclosed by an additional pellicular membrane (Fig. 4). Tubuli were sparse or absent from host cells infected by merogony stages (Fig. 8 to 11). In such host cells the PV unit membrane contained vestiges or rudiments of funnels, i.e. a shallow or deep invagination filled by an electron-dense substance (Fig. $8 \& 9$ ). Reduction or elimination of the tubular system in some infected cells appeared to coincide with the multiplication of the PV unit membranes (Fig. 9 \& 11). Multiplication of membranes was interrupted where a residual funnel occurred along the PV boundary; these funnels remained connected to a single unit membrane (Fig. 9). Funnel vestiges, i.e. invaginations filled with an electron-dense substance, also occurred on the parasitophorous membrane at the host-parasite interphase of meronts established at the microvillar 

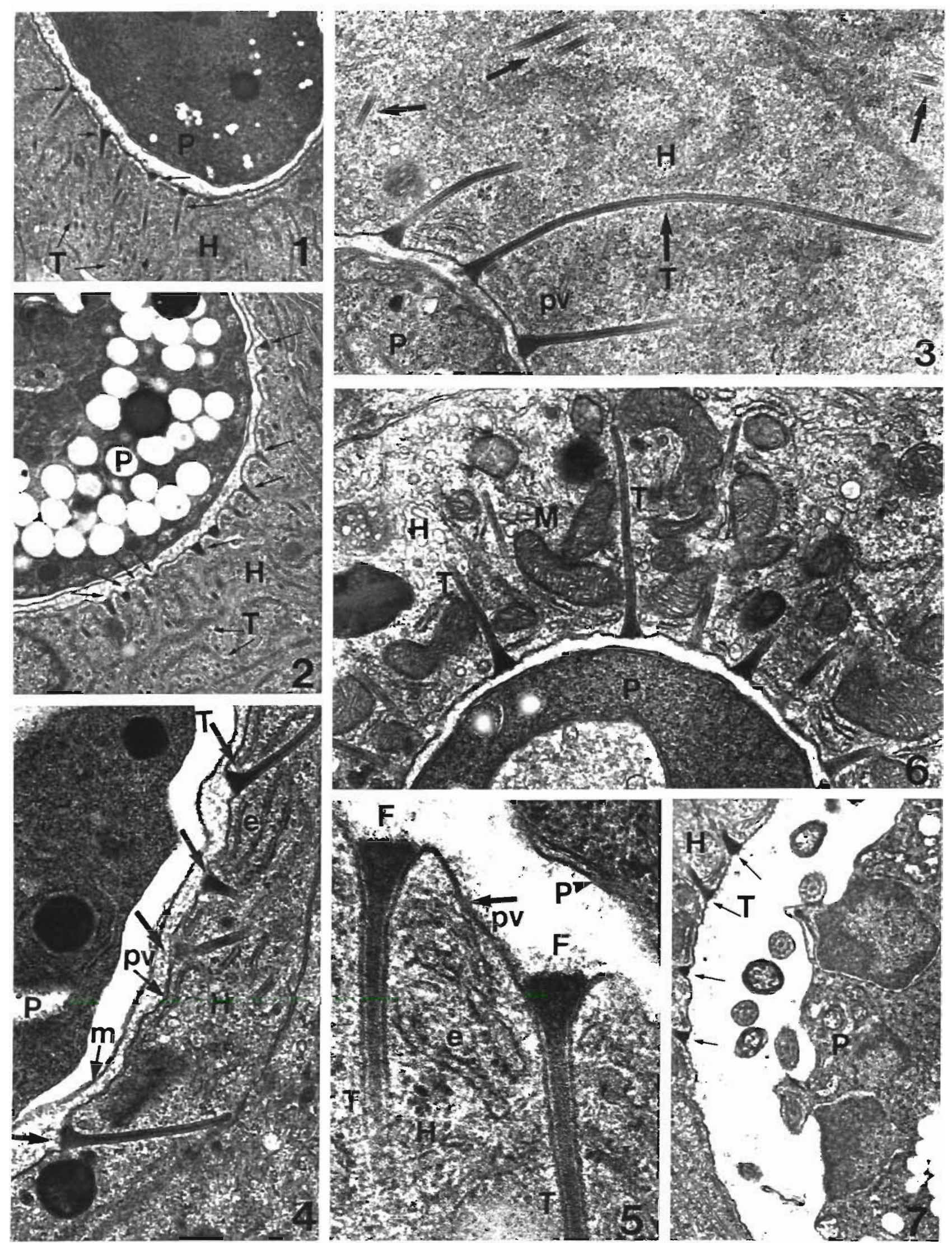

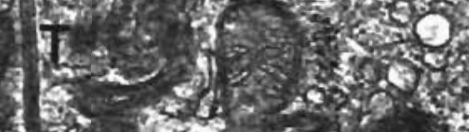

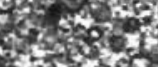

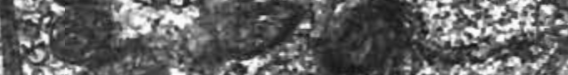

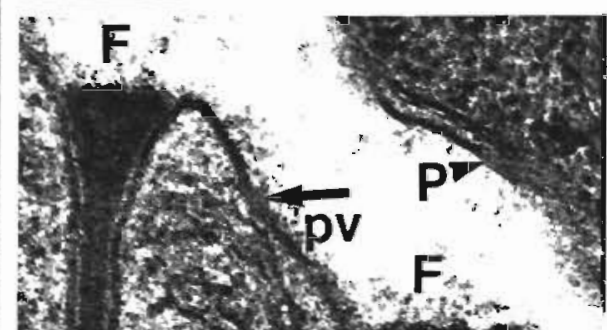

1. $x^{2} \mathrm{y}^{2}$

* thon

*) 2 exty

(1) Th- 3 .

thon 0

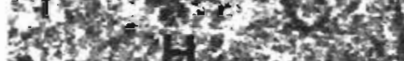

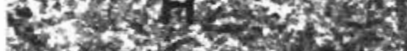
4 the 003

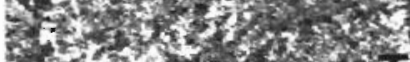
350 . 54 . 23:
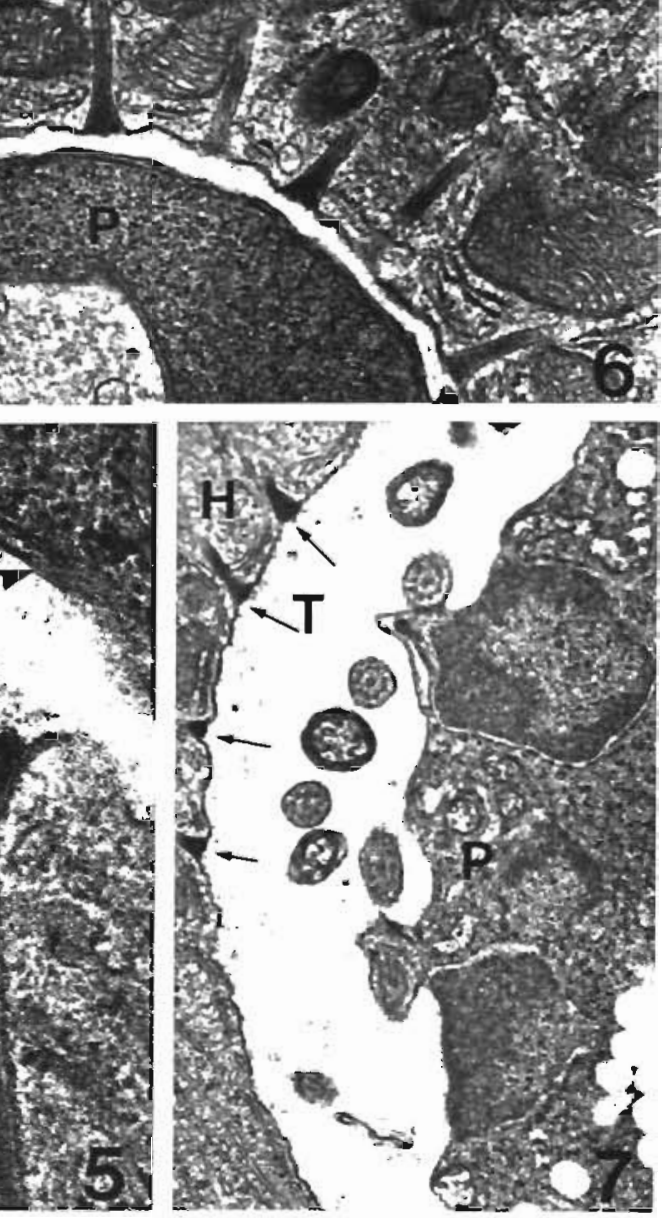

:-

6)

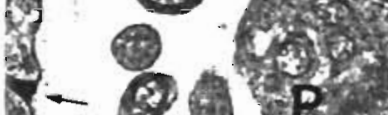

- 8.

a.

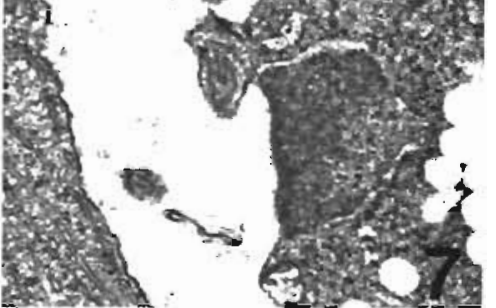



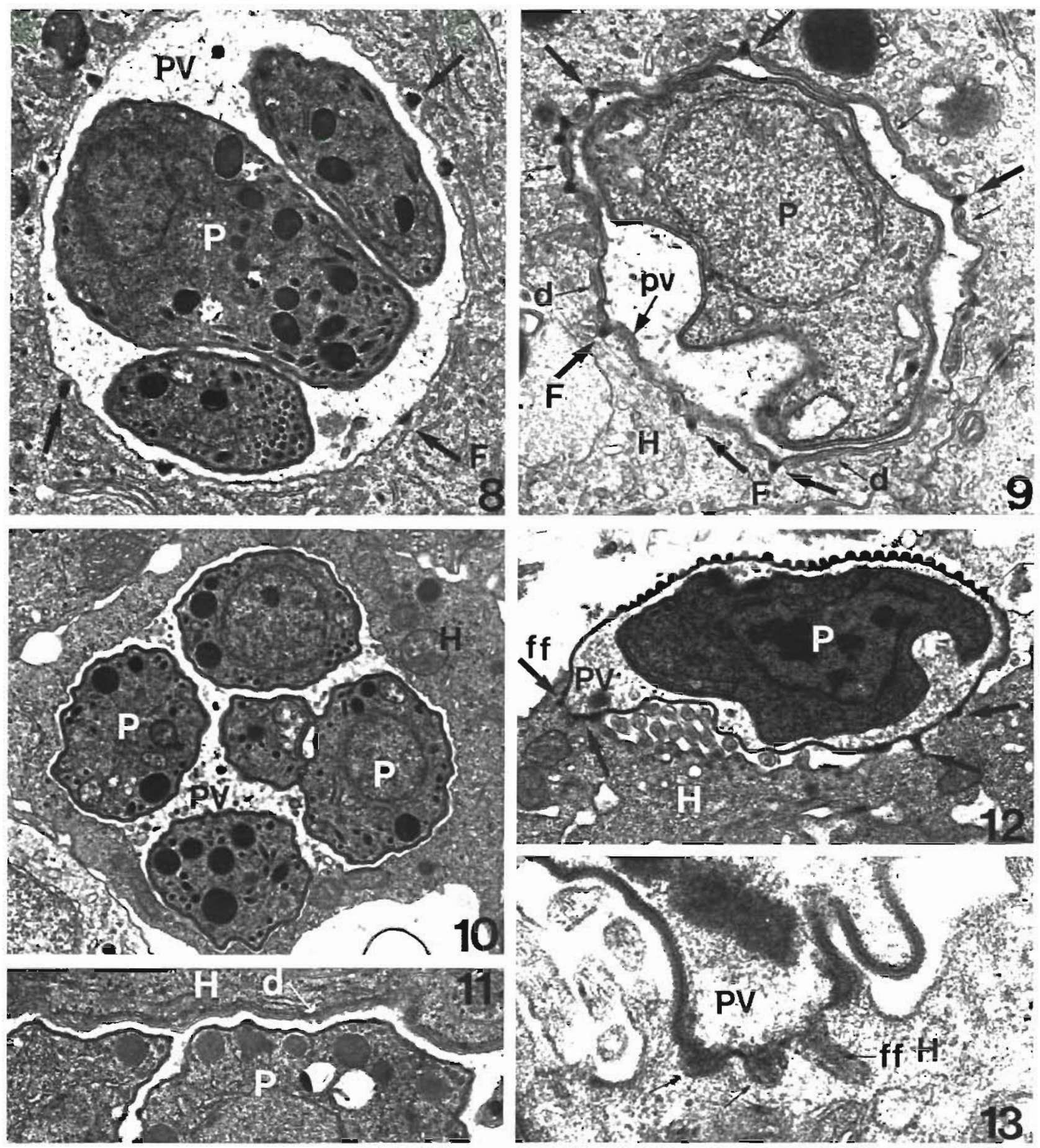

Fig. 1 to 13. Eimeria (s.l.) vanasi infecting Oreochromis aurea $\times$ O. nilotictus. Fig 1 Tubular formations in epithelıal cell infected by juvenile gamont $(\times 1.260)$. Fig. 2. Tubular formations in epithelial cell infected with young zygote $(\times 10000)$ Fig 3 Section showing the length of the tubules $(\times 22800)$ Fig. 4 . Higher magnification view of tubuli and funnels draining into PV containing a young zygote $(\times 25600)$. Fig. 5 . Highly magnified new of funnels and the proximal part of the tubule $(\times 80000)$. Fig. 6 Tubular formation accompanied by numerous mitochondria in a cell infected by a young gamont $(\times 26000)$. Fig. 7. Tubull frngmg a PV containing a microgamont $(\times 10560)$. Fig 8 Reduced occurrence of funnels on the borders of a PV containing melozolte formation $(\times 13700)$. Fig. 9. Reduction in funnels together with duplication of the PV membrane in cells infected with young meronts $(\times 20700)$. Fig. 10. Absence of funnels and tubuli in cell infected by merozoite formation $(\times 12900)$. Fig. 11 . Absence of funnels from PV containing young meronts and bound by multiple membrane wall $(\times 20700)$ Fig 12 Meront located at the microvilar zone of the host cell, vestigial funnels occurnng at the interphase between the PV and cytoplasm of the host cell (arrows) $(\times 16000)$. Fig. 13. Highly magnified vew of the vestıgial funnel associated with PV's of miciovillar zone infections $(\times 55700)$

Abbreviations to figures. d: multimembrane wall of the parasitophorous vacuole, e endoplasmıc reticulum, F. funnel, ff- vestıglal funnel; $\mathrm{H}$ : host cell; $\mathrm{M}$ : mitochondria, m pellıcular membrane; $\mathrm{p}$ parasite, PV parasitophorous vacuole. pv wall of the pasasitophorous vacuole; $T$ tubulı 
zone of mucosal host cells (Fig. $12 \& 13$ ). These invaginations are structurally similar to the parasitophorous protrusions described in Epieimeria isabellae (Daoudi et al. 1985) and in E. anquillae (Molnár \& Baska 1986). This implies the possible existence of a tubular system in Epieimeria species. It also suggests a close relationship of this eimerine coccidium to Epieimeria.

To the best of our knowledge a tubular system such as that presently described has not been reported in any other intracellular host-parasitic protozoan relationship. The function of this tubular system remains at present unknown. Intravacuolar tubules like those reported in infections by macrogamonts of Eimeria and Isospora (Michael 1975, Milde 1979) are very distinct from the tubular system reported here. The former tubular system, which was suggested to transfer nutrients from the host cytoplasm into the parasite, appeared to connect the parasite cytoplasm with the host cell.

Acknowledgement. Research was supported by a grant from the Council for Scientific and Industrial Research, Republic of
South Africa, through Rand Afrikaans University, Johannesburg.

\section{LITERATURE CITED}

Daoudi, F., Marques, A., Bouix, G. (1985). Ultrastructure d'Epieimeria isabellae Lom et Dykova, 1982 coccidie epicellulaire parasite intestinal du poisson teleosteen Conger conger Linne, 1758. Society of Protozoologists, Abstracts (1985), No. 114: 35

Dyková, I., Lom, J. (1981). Fish coccidia: critical notes on life cycles, classification and pathogenicity. J. Fish Dis. 4: $487-505$

Landsberg, J. H., Paperna I. (in press). Intestinal infections by Eimeria (s.l.) vanasi n. sp. (Eimeridae, Apicomplexa, Protozoa) in cichlid fish. Annls Parasit. hum. comp.

Michael, E. (1975). Structure and mode of function of organelles associated with nutrition of the macrogametes of Eimeria acervulina. Z. ParasitKde 45: 347-361

Milde, K. (1979). Light and electron microscope studies on isosporan parasites (Sporozoa) in sparrows (Passer domesticus). Protistologica 15: 607-627

Molnár, K., Baska, F. (1986). Light and electron microscope studies on Epieimeria anquillae (Léger and Hollande, 1922), a coccidian parasitizing the European eel Anguilla anguilla L. J. Fish Dis. 9: 99-110 